BIBLIOTIKA : Jurnal Kajian Perpustakaan dan Informasi

Volume 2 Nomor 1, 2018

Journal homepage : http://journal2.um.ac.id/index.php/bibliotika

\title{
KONTEN AKUN MEDIA SOSIAL TWITTER PERPUSTAKAAN UNIVERSITAS PERGURUAN TINGGI DI INDONESIA
}

\author{
M. Taufikurahman Akbar*, Martutik, Moh. Safii \\ Universitas Negeri Malang, Indonesia
}

\begin{tabular}{|c|c|}
\hline A R T ICLE INFO & A B S T R AC T \\
\hline $\begin{array}{l}\text { Keyword: } \\
\text { Konten, } \\
\text { Akun Media Sosial Twitter, } \\
\text { Perpustakaan }\end{array}$ & $\begin{array}{l}\text { Penelitian ini bertujuan mendeskripsikan konten akun media sosial Twitter Perpustakaan } \\
\text { Universitas Indonesia @UI_Library dan Perpustakaan Universitas Airlangga @Unairlibrary } \\
\text { yang termasuk dalam katagori sifat konten, layanan perpustakaan, dan bentuk berita. } \\
\text { Penelitian ini menggunakan jenis penelitian analisis isi kuantitatif dengan pendekatan } \\
\text { deskriptif. Hasil penelitian menunjukan konten informasi, event, bimbingan pemakai, } \\
\text { humas dan tulisan bergambar adalah konten dari masingmasing unit analisis yang jumlah } \\
\text { komentar, retweet dan like lebih dominan diminati oleh pemustaka daripada konten } \\
\text { ajakan, layanan referensi, sirkulasi, dan tulisan. }\end{array}$ \\
\hline
\end{tabular}

\section{PENDAHULUAN}

Sejak diperkenalkannya Library 2.0 pada Agustus 2005 oleh Michael Casey (Casey and Savastinuk: 2007) banyak perpustakaan di dunia mulai ikut membicarakan hal yang sama. Yang paling menarik dari keberadaan Library 2.0 adalah adanya keterlibatan pemustaka dalam memaksimalkan pelayanan yang ada pada perpustakaan . Perpustakaan tidak hanya memiliki sebuah fungsi sebagai ruangan atau gedung penyedia sumber informasi, akan tetapi dengan adanya hal tersebut perpustakaan juga memiliki tujuan untuk mengikutsertakan pemustaka dalam memanfaatkan media sosial dalam penyebaran informasi. Semakin berkembangnya jejaring sosial seperti saat ini tidak menutup kemungkinan jika perpustakaan ikut serta dalam mengoptimalkan suatu layanan ataupun produk yang dimiliki melalui ranah jejaring social (Almas, 2017).

Dilihat dari hal tersebut keberadaan media sosial Twitter tidak menutup kemungkinan bisa dimanfaatkan sebagai media interaksi bagi perpustakaan dengan pemustaka. Agar mampu menjalin hubungan baik dengan pemustaka, perpustakaan hendaknya mampu mengikuti perkembangan zaman karena seiring dengan perkembangan zaman maka semakin berkembang pula generasi yang ada.

Di kalangan masyarakat, Twitter telah menarik perhatian beberapa lembaga untuk dimanfaatkan dalam kegiatan mereka. Tingginya pengguna internet di Indonesia memberikan pengaruh terhadap tingginya pengguna Twitter. Berikut adalah data statistik akun resmi Twitter perpustakaan perguruan tinggi yang dari masing-masing kota di Indonesia:

Tabel.1.2 Akun Resmi Twitter Perpustakaan Perguruan Tinggi di Indonesia

\begin{tabular}{|l|c|l|l|}
\hline Nama Perguruan Tinggi & Nama Akun Twitter & $\begin{array}{l}\text { Tahun } \\
\text { Berdiri }\end{array}$ & $\begin{array}{l}\text { Jumlah Followers } \\
\text { (September 2017) }\end{array}$ \\
\hline Universitas Indonesia & @UI_Library & April 2011 & 23.606 Pengikut. \\
\hline Universitas Airlangga & @Unairlibrary & Desember 2011 & 6.159 Pengikut. \\
\hline
\end{tabular}

* Corresponding author.

E-mail addresses: Opickituakbar@gmail.com (M. Taufikurahman Akbar)

ISSN : 2579-3802 (Online) - BIBLIOTIKA : Jurnal Kajian Perpustakaan dan Informasi is licensed under Creative Commons AttributionShareAlike 4.0 International License (http://creativecommons.org/licenses/BY/4.0/).

41 | BIBLIOTIKA : Jurnal Kajian Perpustakaan dan Informasi 


\begin{tabular}{|c|c|c|c|}
\hline UIN Sunan Kalijaga & @Uinjogjalib & |Juni 2011 & 2.640 Pengikut. \\
\hline Universitas Negeri Jakarta & @PerpustakaanUNJ & Oktober 2013 & 289 Pengikut. \\
\hline $\begin{array}{l}\text { Universitas } \\
\text { Muhammadi } \\
\text { yah } \\
\text { Yogyakarta }\end{array}$ & $\begin{array}{l}@ P e r p u s t a k a a n U M \\
Y\end{array}$ & $\begin{array}{l}\text { September } \\
2016\end{array}$ & 221 Pengikut. \\
\hline Universitas Negeri Malang & $\begin{array}{l}\text { @Perpustakaan_U } \\
M\end{array}$ & $\begin{array}{c}\text { November } \\
2014\end{array}$ & 176 Pengikut. \\
\hline Universitas Brawijaya & @UBLibraryMlg & Januari 2015 & 150 Pengikut. \\
\hline Universitas Diponogoro & @Undip_library & Juni 2010 & 74 Pengikut. \\
\hline $\begin{array}{ll}\text { Universitas } & \text { Sumatera } \\
\text { Utara } & \end{array}$ & @USU Library & $\begin{array}{l}\text { September } \\
2009\end{array}$ & 9 Pengikut. \\
\hline
\end{tabular}

Sumber: Akun Media Sosial Twitter Perpustakaan Perguruan Tinggi di Indonesia

Data statistik tersebut menunjukkan bahwa setiap perpustakaan khususnya Perpustakaan Perguruan Tinggi telah memanfaatkan keberadaan media sosial Twitter dalam penyebaran informasi. Perpustakaan Universitas Indonesia berada pada urutan pertama dengan jumlah pengikut 23.606 ribu dan Perpustakaan Universitas Airlangga berada pada urutan kedua yaitu dengan jumlah pengikut 6.159 ribu yang didapatkan melalui masing-masing akun media sosial Twitter Perpustakaan Universitas Indonesia dan Perpustakaan Universitas Airlangga. Melihat tingginya pengikut akun Twitter dari masing-masing akun media sosial Twitter Perpustakaan Perguruan Tinggi tersebut, memberikan suatu alasan bagi peneliti untuk mengkaji sebuah penelitaian mengenai pemanfaatan akun media sosial Twitter pada perpustakaan. Universitas Indonesia dan Universitas Airlangga.

Seperti yang telah dikaji pada penelitian sebelumnya oleh Tyas Eka Damayanti yang berjudul "Pemanfaatan Twitter Sebagai Media Information Sharing Di Perpustakaan (Studi Kasus Tentang Pemanfaatan Media Sosial Twitter Sebagai Media Information Sharing di Perpustakaan Wilayah Kota Surabaya)" disimpulkan bahwa dalam penyebaran informasi kepada pengguna perpustakaan melalui akun media sosial Twitter, informasi yang menarik dan memiliki satu nilai kepentingan yang tinggi dan lebih mampu menarik minat pengguna terhadap akun ataupun terhadap respon yang diberikan secara baik dalam dunia maya ataupun dunia nyata. Pertukaran informasi yang terjadi antara perpustakaan dengan pemustaka belum dapat berjalan dengan maksimal, hal ini perlu dilakukan penelitian lebih lanjut yang meneliti dari segi pengguna. Karena sejatinya perpustakaan telah melakukan hal yang inovatif untuk mengundang adanya respon dan sharing dari pengguna, namun tetap saja pengguna kurang memberikan apresiasi yang sepenuhnya terhadap inovasi perpustakaan tersebut.

Banyaknya kemudahan yang bisa didapat oleh perpustakaan dengan memanfaatkan akun media sosial Twitter. Mulai dari penyebaran informasi dengan sangat mudah hingga memberikan keefisienan waktu bagi pemustaka dalam pengaksesan informasi perpustakaan. Cara seperti ini secara tidak langsung akan menciptakan suatu jalinan serta keakraban antara pemustaka dengan perpustakan melalui sebuah percakapan singkat melalui akun media sosial Twitter. Penelitian ini bertujuan untuk memberikan kemudahan untuk perpustakaan untuk mengetahui lebih dalam mengenai pemanfaatan media sosial Twitter dalam peyebaran informasi dan secara tidak langsung akan lebih mengetahui informasi aa yang lebih diminati oleh pemustaka yang dilihat dari konten pada postingan akun media sosial Twitter Perpustakaan Universitas Indonesia dan Perpustakaan Universitas Airlangga.

\section{METODE}

Penelitian ini berjenis analisis isi kuantitatif dengan pendekatan deskriptif. Subjek yang digunakan pada penelitian ini adalah akun media sosial Twitter Perpustakaan Universitas Indonesia @UI_Library dan Perpustakaan Universitas Airlangga @Unairlibrary. Objek yang digunakan dalam penelitian ini adalah konten akun media sosial Twitter yang termasuk dalam kategori sifat konten (informasi, ajakan) layanan perpustakaan (layanan sirkulasi, layanan referensi, bimbingan pemakai, event, humas) bentuk berita (tulisan dan tulisan bergambar) serta jumlah komentar, jumlah retweet dan jumlah like yang termuat 
dalam akun media sosial Twitter Perpustakaan Universitas Indonesia @UI_Library dan akun media sosial Twitter Perpustakaan Universitas Airlangga @Unairlibrary.

Teknik pengumpulan data yang digunakan adalah analisis pencatatan sintaksis. Langkah-langkah yang dilaksanakan dalam pengumpulan data sebagai berikut. Pertama, mengamati secara teliti konten informasi yang termuat pada akun media sosial Twitter Perpustakaan Universitas Indonesia @UI_Library yang diunggah pada periode bulan Oktober 2016 sampai bulan Oktober 2017 dan akun media sosial Twitter Perpustakaan Universitas Airlangga @Unairlibrary yang diunggah pada periode bulan Februari sampai bulan Oktober 2017. Kedua, mengkategorikan setiap data yang didapat berdasarkan konten akun media sosial Twitter yang termasuk dalam katagori (informasi, ajakan, layanan perpustakaan, bentuk berita seperti tulisan dan tulisan bergambar serta jumlah komentar, jumlah retweet dan jumlah like). Ketiga, menjumlah dan mempresentasikan data yang telah dikelompokan.

Populasi dalam penelitian ini adalah seluruh tweet yang disajikan oleh akun media sosial Twitter Perpustakaan Universitas Indonesia @UI_Library dan Perpustakaan Universitas Airlangga @Unairlibrary. Sedangkan sampel pada penelitian ini adalah konten akun media sosial Twitter yang termasuk dalam kategori sifat konten (informasi, ajakan) layanan perpustakaan (layanan sirkulasi, layanan referensi, bimbingan pemakai, event, humas) bentuk berita (tulisan dan tulisan bergambar) serta jumlah komentar, jumlah retweet dan jumlah like yang diambil pada akun media sosial Twitter Perpustakaan Universitas Indonesia @UI_Library pada periode bulan Oktober 2016 sampai Oktober 2017 dan akun media sosial Twitter Perpustakaan Universitas Airlangga @Unairlibrary pada periode bulan Februari 2017 sampai Oktober 2017.

Instrumen penelitian dalam penelitian ini adalah peneliti bertindak sebagai instrumen utama, menggunakan masing-masing akun Twitter perpustakaan yang dijadikan sebagai alat dan bahan dalam penelitian. Setelah proses pengumpulan data peneliti menggunakan Microsoft Excel sebagai alat perhitungan data.

Metode analisis data pada penelitian ini dilakukan secara deskriptif yaitu dengan cara menjelaskan unit analisis pada akun media sosial Twitter Perpustakaan Universitas Indonesia @UI_Library dan akun media sosial Twitter Perpustakaan Universitas Airlangga @Unairlibrary berdasarkan konten akun media sosial Twitter yang termasuk dalam sifat konten (informasi, ajakan) layanan perpustakaan (layanan sirkulasi, layanan referensi, bimbingan pemakai, event, humas) bentuk berita (tulisan dan tulisan bergambar) serta jumlah komentar, jumlah retweet dan jumlah like.

Langkah-langkah dalam menganalisis data pada penelitian ini sebagai berikut. Pertama Mendeskripsikan temuan-temuan yang masuk dalam katagori yang telah ditentukan. Kedua Menghitung data hasil temuan dengan menggunakan rumus berikut.

$P \%=\frac{\sum q}{r} x 100$

$\mathrm{P} \%=$ Skor presentase yang diperoleh

$\Sigma \mathrm{q}=$ Jumlah kesesuaian dalam teks dan keterangan dengan descriptor

$\Sigma \mathrm{r}=$ Jumlah seluruh konten yang masuk kedalam katagori yang diunggah pada kedua akun Twitter perpustakaan

Ketiga Memberikan skor penilaian sesuai dengan presentase yang diperoleh. Keempat Menjumlahkan skor pada masing-masing unit analisis sehingga memperoleh skor ratarata. Dari skor ratarata tersebut kemudian disimpulkan hasil yang didapatkan berdasarkan katagori unit yang dianalisis berdasarkan kriteria sebagai berikut.

Validitas yang digunakan pada penelitian ini adalah validitas isi (Content Validity). Reliabilitas terdiri atas lembar coding yang berjumlah 20 item. Untuk perhitungan reliabilitas menggunkan rumus:

Reliabilitas antar - Coder $=\frac{\mathrm{A}}{\mathrm{N}}$

Keterangan: $\mathrm{A}=$ Jumlah Persetujuan dari Dua Coder

$\mathrm{B}=$ Jumlah Unit yang dites

Reliailitas pada penelitian ini menujukan angka 0,80 atau jika dihitung dalam hitungan persentase sebesar $80 \%$.

HASIL

Data yang didapatkan melalui akun media sosial Twitter Perpustakaan Universitas Indonesia @UI_Library periode bulan Oktober 2016 sampai Oktober 2017 sebanyak 261 postingan dan Universitas Airlangga @Unairlibrary periode bulan Februari 2017 sampai Oktober 2017 sebanyak 521 data. Dari data keseluruhan diperoleh beberapa hasil analisis konten informasi perpustakaan yang termasuk kategori unit analisis seperti sifat konten (informasi, ajakan) layanan perpustakaan (layanan sirkulasi, layanan referensi, 
bimbingan pemakai, event, humas) bentuk berita (tulisan dan tulisan bergambar) serta jumlah komentar, jumlah retweet dan jumlah like.

Tabel 1 Total Perolehan Data Unit Analisis Sifat Konten, Layanan, Bentuk Berita @UI_Library dan @Unairlibrary Berdasarkan Jumlah Komentar, Jumlah Retweet, dan Jumlah Like

\begin{tabular}{|c|c|c|c|c|c|c|c|}
\hline \multirow[b]{2}{*}{ Unit Analisis } & \multirow[b]{2}{*}{ Kategori } & \multicolumn{3}{|c|}{ (a)I_Library } & \multicolumn{3}{|c|}{ (a)Unairlibrary } \\
\hline & & $\mathbf{L}$ & $\mathbf{R}$ & $\mathbf{K}$ & $\mathbf{L}$ & $\mathbf{R}$ & $\mathbf{K}$ \\
\hline \multirow[b]{2}{*}{ Sifat Konten } & Informasi & 70 & 455 & 501 & 19 & 63 & 148 \\
\hline & Ajakan & 18 & 63 & 649 & 18 & 11 & 63 \\
\hline \multirow{5}{*}{ Layanan } & Referensi & 35 & 167 & 235 & 0 & 4 & 4 \\
\hline & Sirkulasi & 28 & 126 & 149 & 1 & 5 & 4 \\
\hline & $\begin{array}{c}\text { Bimbingan } \\
\text { Pemakai }\end{array}$ & 11 & 42 & 68 & 19 & 45 & 75 \\
\hline & Humas & 22 & 211 & 241 & 1 & 15 & 63 \\
\hline & Event & 38 & 202 & 159 & 12 & 36 & 89 \\
\hline \multirow[b]{2}{*}{ Bentuk Berita } & Tulisan & 22 & 132 & 151 & 14 & 36 & 47 \\
\hline & $\begin{array}{c}\text { Tulisan dan } \\
\text { Gambar }\end{array}$ & 109 & 662 & 687 & 15 & 70 & 137 \\
\hline
\end{tabular}

Keterangan: L: Like

$\mathrm{R}$ : Retweet

K: Komentar

Sumber: Akun Media Sosial Twitter Perpustakaan Universitas Indonesia Perpustakaan Universitas Airlangga @Unairlibrary

@UI_Library dan

Tabel 1 memberikan penjelasan bahwa. Pertama, sifat konten yang lebih dominan diminati oleh pemustaka jika dilihat dari jumlah Like, Retweet, Komentar pada akun media sosial Twitter Perpustakaan Universitas Indonesia @UI_Library dan Perpustakaan Universitas Airlangga @Unairlibrary adalah sifat konten kategori informasi. Kedua, analisis konten akun media sosial Twitter Perpustakaan Universitas Indonesia@UI_Library berdasarkan layanan perpustakaan yang lebih dominan diminati oleh pemustaka khususnya warga sivitas akademik maupun sivitas nonakademik jika diambil dari tingginya minat pemustaka dalam me-Retweet dan menyukai sebuah postingan melalui fitur Like, konten layanan yang lebih dominan di Retweet dan di Like adalah layanan humas perpustakaan.

Sebaliknya jika dilihat dari tingginya komentar dari akun media sosial Twitter @UI_Library layanan yang lebih dominan dikomentari oleh masyrakat adalah layanan event perpustakaan. Sedangkan pada akun media sosial Twitter Perpustakaan Universitas Airlangga @Unailibrary jika dilihat dari tingginya jumlah komentar dan Retweet layanan perpustakaan yang lebih dominan dikomentari dan di Retweet oleh pemustaka khususnya warga sivitas akademik maupun non akademik adalah layanan bimbingan pemakai perpustakaan.

Jika dilihat dari tingginya minat pemustaka dalam menyukai konten akun media sosial Twitter @Unairlibrary jika dilihat dari tingginya jumlah Like konten Twitter yang lebih dominan di Like adalah koten event perpustakaan. Ketiga, analisis konten akun media sosial Twitter Perpustakaan Universitas Indonesia@UI_Library dan Perpustakaan Universitas Airlangga @Unairlibrary berdasarkan konten bentuk berita kategori tulisan, tulisan dan gambar, yang lebih dominan diminati oleh pemustaka khususnya warga sivitas akademik maupun sivitas nonakademik adalah konten tulisan dan gambar.

PEMBAHASAN

Analisis Konten Akun Media Sosial Twitter Perpustakaan Berdasarkan Kategori

Sifat Konten

Akun media sosial Twitter Perpustakaan Universitas Indonesia

Hasil analisis konten akun media sosial Twitter Perpustakaan Universitas Indonesia @UI_Library memberikan penjelasan bahwa sifat konten dari kategori konten informasi dan ajakan yang lebih dominan 
diminati oleh pemustaka khususnya warga sivitas akademik maupun non akademik yang dihitung berdasarkan jumlah komentar, jumlah like dan jumlah retweet yaitu kategori konten informasi. Tingginya minat pemustaka akan konten informasi yang disebarluaskan melalui akun media sosial Twitter dipengaruhi oleh beberapa faktor diantarnya:

a. Perkembangan teknologi di Indonesia sudah semakin pesat sehingga memudahkan para masyarakat untuk mengakses informasi dan memanfaatkan informasi melalui saluran internet dan media sosial ataupun gadged yang dimikinya (Lawanda 2015:30). Sesuai dengan laporan index 2017 yang belum lama diluncurkan ada sekitar 132 juta atau setara 51,7\% terhadap populasi 265,2 jiwa. Sementara ada tiga besar jenis konten internet yang diakses pengguna, yakni media sosial 129,2 juta (97,7\%), hiburan 128,4 juta $(96,8 \%)$ dan berita 127.9 juta $(96,4 \%)$. Hal ini memberikan suatu alasan yang jelas bahwa masyarakat Indonesia lebih menyukai sebuah informasi yang dikemas dalam bentuk media sosial, bahkan sekalipun konten informasi perpustakaan yang sampaikan oleh Perpustakaan Universitas Indonesia melalui akun media sosial Twitter.

b. Letak Universitas Indonesia pada wilayah provinsi jawa barat yang tingkat penduduknya sangat tinggi yaitu sekitar 46,8 juta jiwa dan tingkat pengguna internet terbanyak ada di pulau Jawa dengan total pengguna 86, 339, 350 user atau sekitar 65\% dari total pengguna internet di Indonesia.

c. Personalitas yaitu aspek psikologi dari pencari informasi meliputi, ketepatan, ketekunan mencari informasi, pencarian secara sistematik, motivasi dan kemauan yang tinggi dalam menerima informasi (Nicholas 2009:57).

d. Mempunyai kebutuhan yang berbeda yaitu pada umumnya bahwa, hal yang mempengaruhi perilaku manusia karena adanya dorongan dari serangkaian kebutuhan. Dengan kebutuhan ini dimaksudkan adalah beberapa pernyataan dalam diri seseorang (internal state) yang menyebabkan seseorang itu berbuat untuk mencapainya sebagai suatu objek atau hasil. Disisi lain hal ini juga dapat membantu perpustakaan untuk memahami mengapa informasi dianggap penting bagi seseorang, dan juga membantu kepada kita untuk mengerti hasil manakah yang akan menjadi titik terpenting untuk menentukan spesifikasi individu (Thoha 2002:33).

Selain itu jika dikaitkan dengan aspek sosiologi pengguna informasi, hal yang menyebabkan konten informasi jauh lebih disukai oleh pemustaka dibandingankan konten ajakan pada akun media sosial Twitter Perpustakaan Universitas Indonesia @UI_Library, karena setiap pemustaka memiliki perbedaan dan karakteristik termasuk perbedaan jenis dan tingkat kebutuhannya. Menurut Rakhmat (1993:198) kelompok sosial tertentu yang ada di masyarakat itu beragam, namun dari setiap kelompok mempunyai kecendrungan orientasi yang sama atau hampir sama terhadap terhadap objek yang ada kaitannya dengan kepentingan kelompok maupun kepentinga individu itu sendiri. Dari konsep ini jelas bahwa pemustaka akan lebih menyukai konten informasi dari suatu media tertentu. Golongan sosial berdasarkan usia, jenis kelamin, tingkat pendapatan, pendidikan, tempat tinggal dan keyakinan akan mempunyai kecendrungan memilih informasi karena akan memberikan respon positif kepada dirinya pula.

\section{Akun media sosial Twitter Perpustakaan Universitas Airlangga}

Hasil analisis konten akun media sosial Twitter Perpustakaan Universitas Airlangga @Unairlibrary memberikan penjelesan bahwa sifat konten dari kategori konten informasi dan ajakan yang lebih dominan diminati oleh pemustaka khususnya warga sivitas akademik maupun non akademik yang dihitung berdasarkan jumlah komentar, jumlah like dan jumlah retweet yaitu kategori konten informasi. Tingginya minat pemustaka akan konten informasi karena setiap pemustaka mempunyai kebutuhan dan keinginan tertentu sesuai dengan apa yang diharapkan. Selain itu adanya motif pemustaka yang ingin tahu akan segala sesuatu yang dapat meningkatkan kualitas hidupnya menyebabkan pemustaka tersebut berusaha untuk mendorong keinginanya untuk mencapai apa yang diinginkan dengan cara mencari agar mendapatkan sesuatu tersebut (Pawit 2014 335).

Hal ini jika dikaitkan dengan tingginya minat pemustaka yang lebih menyukai konten informasi dibandingkan konten ajakan pada akun media sosial Twitter Perpustakaan Universitas Airlangga @Unairlibrary, karena setiap orang sangat membutuhkan informasi sebab informasi sebagai bagian dari tuntutan kehidupan, sebagai penunjang kegiatannya dan sebagai pemenuhan kebutuhan. Menurut Krech (1962:99) yaitu adanya kebutuhan untuk memecahkan masalah-masalah sosial maka seseorang termotivasi untuk mencari pengetahuan agar dapat memecahkan masalah tersebut. Dengan demikian tingginya minat pemustaka akan konten informasi yang dikemas melalui akun media sosial Twitter oleh Perpustakaan Universitas Airlangga karena adanya rasa ingin tahu yang dimiliki oleh pemustaka. Disisi lain pemustaka juga selalu berusaha untuk menambah pengetahuanya bahkan melalu informasi yang dikemas oleh perpustakaan melalui akun media sosial Twitter: 
Menurut Krech (1962:84) timbulnya kebutuhan seseorang akan informasi dipengaruhi oleh kondisi fisiologi, sistuasi, dan kognisinya. Kebutuhan orang akan timbul atas barang-barang yang tidak terjangkau oleh kemampuan daya belinya. Cara berfikir seseorang juga akan menimbulkan keinginan atau kebutuhan tertentu yang sesuai dengan apa yang dipikirkannya. Misalnya, jika seseorang sedang berfikir tentang bagaimana cara meningkatkan kemampuan yang sudah dimilikinya, maka ia akan berfikir tentang upaya mencari informasi untuk tujuan-tujuan tersebut, termasuk dengan membaca media bacaan yang yang sesuai dengan kebutuhan. Jika dikaitkan dengan tingginya minat pemustaka akan konten informasi pada akun media sosial Twitter Perpustakaan Universitas Airlangga @Unairlibrary, ini dikarenakan setiap pemustaka pasti miliki keinginan yang tinggi untuk meningkatkan kemampuannya dalam berbagai hal yang diinginkan dengan cara mendapatkan informasi tersebut melalui berbagai macam sarana media komunikasi seperti media sosial Twitter.

\section{Analisis Konten Akun Media Sosial Twitter Perpustakaan Berdasarkan Kategori Layanan Perpustakaan \\ Akun media sosial Twitter Perpustakaan Universitas Indonesia}

Hasil analisis konten akun media sosial Twitter Perpustakaan Universitas Indonesia @UI_Library memberikan penjelasan bahwa dari kategori konten layanan perpustakaan yang disebarkan melalui akun media sosial Twitter, konten informasi layanan yang lebih dominan diminati oleh pemustaka khususnya warga sivitas akademik maupun sivitas non-akademik yang dihitung berdasarkan jumlah like dan jumlah retweet yaitu kategori konten layanan humas perpustakaan. Tingginya minat pemustaka terhadap informasi konten layanan humas perpustakaan dipengaruhi oleh komunikasi yang efektif.

Melalui akun media sosial Twitter Perpustakaan Universitas Indonesia mampu menciptakan komunikasi efektif dua arah antara perpustakaan dengan pemustaka. Adanya komunikasi yang efektif tidak terlepas dari perencanaan tentang bagaimana cara perpustakaan mengkomunikasikan dan apa yang akan dikomunikasikan kepada masyarakat mengenai suatu informasi yang dapat memecahkan permasalahan pemustaka dengan memanfaatkan sumber-sumber teknologi informasi seperti yang sedang berkembang saat ini. Selain itu tingginya arus informasi dari perpustakaan memberikan pengaruh pula terhadap tingginya minat pemustaka untuk menyebarluaskan kembali informasi yang didapat dari media sosial Twitter Perpustakaan Universitas Indonesia melalui fitur Retweet dan Like yang ada pada media sosial Twitter agar masyarakat lain dapat mengetahui informasi yang kemas oleh Perpustakaan Universitas Indonesia melalui akun media sosial Twitter(Murtedjo 2004).

Hal diatas juga dapat dijadikan sebagai sebuah alasan mengapa tingginya jumlah komentar pada konten layanan event perpustakaan di akun media sosial Twitter Perpustakan Universitas Indonesia @UI_Library karena tingginya keterampilan intlektual pemustaka dalam berargumentasi secara rasional dan kritis. Selain itu pandangan moral pemustaka yang berbeda-beda mengakibatkan perbedaan pula minat pemustaka untuk mengomentari setiap layanan Perpustakaan Universitas Indonesia. Dengan demikian adanya etika informasi memberikan suatu pengaruh terhadap tingginya minat pemustaka untuk mengomentari sebuah informasi sebab secara normatif penyebaran informasi yang disajikan oleh Perpustakaan Universitas Indonesia memberikan pengaruh terhadap perilaku pemustaka mengenai apa yang harus dilakukan dan apa yang tidak boleh dilakukakan.

\section{Tingginya kredibilitas yang dimiliki oleh akun media sosial Twitter}

Perpustakaan Universitas Indonesia juga mempengaruhi minat pemustaka untuk meRetweet serta munyukai sebuah postingan pada akun media sosial Twitter @UI_Library. Tingginya tingkat kredibilitas yang dimiliki oleh akun media sosial Twitter Perpustakaan Universitas Indonesia bisa dilihat dari tingginya jumlah follower pada akun media sosial Twitter tersebut yang sampai saat ini berjumlah 23.606 ribu pengikut. Dengan tingginya jumlah pengikut pada akun media sosial Twitter @UI_Library menjadikan sebuah alasan yang jelas bahwa akun media sosial Twitter Perpustakaan Universitas Indonesia @UI_Library memiliki kredibilitas yang tinggi dalam penyebaran infomasi baik informasi kegiatan atau informasi layanan perpustakan kepada pemustaka. Menurut Source Credibility Theory (Teori Kredibiltas Sumber) yang dikembangkan oleh Hovland, Janis dan Kelley menjelaskan bahwa seseorang mungkin lebih mudah tertarik terhadap suatu informasi atau dibujuk (dipersuasif) jika sumber-sumber persuasinya (bisa komunikator itu sendiri) memiliki kredibilitas yang cukup tinggi, misalnya masyarakat pada umumnya akan lebih percaya dan cenderung menerima dengan baik pesan-pesan yang disampaikan oleh orang yang memiliki kredibilitas dibidangnya (Pawit 2014:114). 


\section{Akun media sosial Twitter Perpustakaan Universitas Airlangga}

Hasil analisis konten akun media sosial Twitter Perpustakaan Universitas Airlangga @Unairlibrary memberikan penjelasan bahwa sifat konten informasi layanan yang lebih dominan diminati oleh pemustaka khususnya warga sivitas akademik maupun non akademik yang dihitung berdasarkan jumlah komentar dan jumlah retweet yaitu kategori konten informasi layanan bimbingan pemakai perpustakaan. Tingginya minat pemustaka terhadap informasi bimbingan pemakai pada akun media sosial Twitter Perpustakaan Universitas Airlangga disebabkan oleh adanya interaksi yang tinggi antara pemustaka dengan perpustakaan, baik pemustaka sivitas akademik maupun pemustaka sivitas non akademik.

Jika dikaitkan dengan teori interaksi, fenomena yang menyebabkan tingginya minat pemustaka dalam memberikan komentar dan me-retweet konten informasi layanan bimbingan pemakai pada akun media sosial Twitter @Unairlibrary disebabkan oleh tingginya proses bimbingan pemakai yang terjadi didalam lingkungan perpustakaan tersebut. Proses yang dimaksud adalah adanya berbagai macam kegiatan bimbingan pemakai seperti layanan Library Class yang memberikan berbagai macam bentuk bimbingan pemakai perpustakaan baik dari bimbingan non teknis maupun bimbingan teknis dari kegiatan yang dilaksanakan. Dengan demikian tingginya minat pemustaka untuk mengomentari dan menyebarkan informasi melalui fitur Retweet pada akun media sosial Twitter mengenai informasi konten bimbingan pemakai perpustakaan disebabkan oleh tingginya proses komunikasi antarkomponen (orang, media, bahan, alat, lingkungan dan informasi) yang berjalan secara sinergi dan kompleks menuju arah yang jelas (Effendi 2001:34).

Jika dilihat dari jumlah like pada akun media sosial Twitter Perpustakaan Universitas Airlangga, konten informasi yang lebih dominan disukai oleh pemustaka adalah konten event perpustakaan. Salah satu faktor penting yang mempengaruhi tingginya minat pemustaka akan konten informasi event perpustakaan adalah adanya konsep library as pleace, yaitu kebermanfaatan ruang perpustakaan dimana kenyamanan ruang yang memberikan inspirasi kepada pengguna untuk belajar menjadi indikator yang paling tinggi (Wulandari 2011). Melihat hal tersebut adanya keterbukaan perpustakaan dalam memberikan sarana dan prasarana bagi pemustaka memberikan pengaruh pula terhadap tingginya minat pemustaka lebih menyukai konten informasi event dan melakukan kreasi serta menciptakan inovasi dari sebuah event yang dilaksanakan pada perpustakaan.

\section{Analisis Konten Akun Media Sosial Twitter Perpustakaan Berdasarkan Kategori Bentuk Berita \\ Akun media sosial Twitter Perpustakaan Universitas Indonesia}

Hasil analisis konten akun media sosial Twitter Perpustakaan Universitas Indonesia @UI_Library memberikan penjelesan bahwa bentuk berita dari kategori konten tulisan dan tulisan bergambar yang lebih dominan diminati oleh pemustaka khususnya warga sivitas akademik maupun non akademik yang dihitung berdasarkan jumlah komentar, jumlah like dan jumlah retweet yaitu kategori konten tulisan bergambar (visual). Tingginya minat pemustaka akan informasi dalam bentuk tulisan bergambar (visual) yang yang disebarkan oleh Perpustakaan Universitas Indonesia melalui akun media sosial Twitter @UI_Library karena bentuk berita yang disajikan dalam bentuk tulisan bergambar memiliki daya tarik dan nilai efektivitas yang tinggi (jelas, mudah dimengerti dan mengesankan) bagi si penerima pesan.

Menurut Mark (2012:139) masyarakat akan lebih menyukai informasi yang disajikan dalam bentuk tulisan dan gambar dikarenakan masyarakat dapat dengan cepat menangkap informasi yang disampaikan. Selain itu informasi yang ditangkap secara visual akan diproses sekaligus oleh otak, berbeda dengan informasi dalam bentuk teks yang informasinya akan diproses secara linear dari awal kalimat hingga akhir kalimat. Tingginya minat masyarakat akan informasi dalam bentuk tulisan dan gambar yang dikemas pada akun Twitter Perpustakaan Universitas Indonesia @UI_Library karena informasi yang disajikan sangat mudah untuk dikenali dan dimengerti oleh pemustaka sebab bentuk berita tulisan dan gambar merupakan sebuah cara kreatif untuk mengkomunikasikan informasi secara jelas dan cepat.

\section{Akun media sosial Twitter Perpustakaan Universitas Airlangga}

Hasil analisis konten akun media sosial Twitter Perpustakaan Universitas Indonesia @UI_Library memberikan penjelesan bahwa bentuk berita dari kategori konten tulisan dan tulisan bergambar yang lebih dominan diminati oleh pemustaka khususnya warga sivitas akademik maupun non akademik yang dihitung berdasarkan jumlah komentar, jumlah like dan jumlah retweet yaitu kategori konten tulisan bergambar (visual). Hal ini disebabkan karena informasi yang dikemas yang dikemas dalam bentuk tulisan dan gambar (visual) memiliki kekuatan yang jauh lebih perkasa dibandingkan dengan tulisan. Karena tulisan dan gambar mempunyai kecepatan interprestasi yang sebanding daripada kalimat meskipun katakata lebih cepat untuk disebutkan. Selain itu tingginya minat masyarakat akan konten Informasi dalam 
bentuk tulisan dan gambar karena pemustaka lebih mampu mengikuti sebuah informasi yang bentuknya visual daripada tulisan sebab informasi yang dikemas dalam bentuk visual menjadi satu elemen yang mempunyai kekuatan lebih, bila dibandingkan dengan tulisan, dalam mengubah atau mempengaruhi sikap masyarakat (Mulyana 2001:41).

Tingginya penyebaran informasi mengenai event perpustakaan yang disajikan melalui akun media sosial Twitter Perpustakaan Universitas Airlangga @Unairlibrary memberikan pengaruh pula terhadap tingginya minat pemustaka akan informasi dalam bentuk tulisan dan gambar. Sebab dalam penyampaian informasi dari sebuah kegiatan informasi visual sangat penting keberadaannya. Menurut Mulyana (2001:46) dalam media promosi kegiatan, hendaknya informasi yang sajikan harus dikemas secara medium komunikasi melalui media tulisan dan gambar (visual), agar menekankan suatu pemaknaan yang terkandung didalamnya sehingga dapat dimengerti oleh pembaca walau hanya sepintas dilihat.

Jika hal tersebut diimplementasikan pada fenomena yang sesungguhnya yaitu pada konten akun media sosial Twitter Perpustakaan Universitas Airlangga @Unairlibrary. Tingginya minat pemustaka akan informasi dalam bentuk tulisan dan gambar karana informasi yang dikemas sangat mudah untuk diterima oleh pemustaka. Sebab kunci utama dari penyebaran informasi adalah komunikator harus dapat menarik perhatian komunikan agar komunikan dapat memahami langsung informasi yang disebarkan walau dilihat secara sepintas. Gambar atau ilustrasi yang menarik dan menjadi fokus pada pemaknaan informasi dalam bentuk tulisan dan gambar sangat penting untuk ditampilkan, didukung dengan tipografi yang sesuai serta kata-kata yang singkat namun jelas maknanya (Abhinandan 1999:43).

\section{Kesimpulan}

Pertama, analisis konten akun media sosial TwitterPerpustakaan Universitas Indonesia @UI_Library dan perpustakaan Universitas Airlangga @Unairlibrary berdasarkan sifat konten dari kategori konten informasi dan ajakan, yang lebih dominan diminati oleh pemustaka khususnya warga sivitas akademik maupun non akademik adalah konten informasi.

Kedua, analisis konten akun media sosial Twitter Perpustakaan Universitas Indonesia @UI_Library berdasarkan layanan perpustakaan yang lebih dominan diminati oleh pemustaka khususnya warga sivitas akademik maupun sivitas nonakademik jika diambil dari tingginya minat pemustaka dalam me- Retweet dan menyukai sebuah postingan melalui fitur Like, konten layanan yang lebih dominan di Retweet dan di Like adalah layanan humas perpustakaan. Sebaliknya jika dilihat dari tingginya komentar dari akun media sosial Twitter@UI_Library layanan yang lebih dominan dikomentari oleh masyrakat adalah layanan event perpustakaan. Sedangkan pada akun media sosial Twitter Perpustakaan Universitas Airlangga @Unailibrary jika dilihat dari tingginya jumlah komentar dan Retweet layanan perpustakaan yang lebih dominan dikomentari dan di Retweet oleh pemustaka khususnya warga sivitas akademik maupun nonakademik adalah layanan bimbingan pemakai perpustakaan. Sebaliknya jika dilihat dari tingginya minat pemustaka dalam menyukai konten akun media sosial Twitter @Unairlibrary jika dilihat dari tingginya jumlah Like konten Twitteryang lebih dominan di Like adalah koten event perpustakaan.

Ketiga analisis konten akun media sosial Twitter Perpustakaan Universitas Indonesia @UI_Library dan Perpustakaan Universitas Airlangga @Unairlibrary berdasarkan konten bentuk berita kategori tulisan, tulisan dan gambar, yang lebih dominan diminati oleh pemustaka khususnya warga sivitas akademik maupun sivitas nonakademik adalah konten tulisan dan gambar.

\section{Saran}

Berikut saran dari penelitian ini yang dapat dijadikan masukan bagi pengelola akun media sosial Twitter Perpustakaan Universitas Indonesia dan Perpustakaan Universitas Airlangga dan dapat diterapkan oleh Perpustakaan Perguruan Tinggi yang ada di Indonesia.

Pertama, bagi perpustakaan yang mengelola akun media sosial Twitter hendaknya lebih memperhatikan sifat konten yang disajikan untuk pemustaka misalnya seperti konten informasi yang dikemas secara menarik agar memberikan kesan yang baik pula bagi pemustaka dalam mencari informasi yang berkaitan dengan perpustakaan.

Kedua pemilihan konten informasi layanan perpustakaan hendaknya disesuaikan dengan kebutuhan pemustaka agar mampu meningkatkan promosi layanan perpustakaan. Agar layanan lainnya bisa berjalan bersamaan dengan layanan perpustakaan yang lebih unggul, pengelola akun media sosial Twitter hendaknya mengkemas informasi layanan perpustakaan dengan lebih menarik dari sebelumnya agar mampu menciptakan keseimbangan minat pemustaka dalam pengaksesan informasi layanan perpustakaan.

Ketiga, penyebaran informasi perpustakaan baik dalam bentuk layanan maupun kegiatan, pengelola akun media sosial Twitter perpustakaan hendaknya lebih memperhatikan bentuk berita yang 
disajikan untuk pemustaka. Bentuk berita yang dikemas dalam bentuk visual adalah bentuk berita yang lebih dominan diminati oleh pemustaka daripada tulisan. Dengan demikian unsur visual dalam penyebaran informasi agar lebih diperhatikan lagi untuk menarik minat pemustaka dalam pengaksesan informasi melalui akun media sosial Twitter.

\section{DAFTAR RUJUKAN}

Almas, H. (2017). Manajemen Sistem Informasi Di Perpustakaan Smk Negeri 3 Malang. Bibliotika : Jurnal Kajian Perpustakaan Dan Informasi, 1(1), 91-100.

Damayanti, Eka Tyas. "Pemanfaatan Twitter Sebagai Media Information Sharing di Perpustakaan”.(Online) journal.unair.ac.id. di Akses 11 Agustus 2017 pukul 11:32.

Nicholas David. (2009). Assessing Information needs in the age of the digital customer.

Pawit dan Yusup. (2009). IImu Informasi Komunikasi, dan Kepustakaan. Jakarta: Bumi Aksara.

Rakhmat, Jalaludin. (1993). Psikologi Komunikasi. Edisi Revisi. Bandung:Remadja Rosdakarya.

Wulandari, D. (2011). Mengembangkan Perpustakaan Sejalan dengan Kebutuhan Net Generation. Visi Pustaka. 